\title{
Landscape Design Project of Bursa Tophane Square in the Context of Protection and Development
}

\author{
Nurhan Kocan (Corresponding author) \\ Bartin University, Faculty of Forestry, Department of Landscape Architecture, Bartin, Turkey \\ E-mail: nurhankocan@mynet.com \\ Ferda Nur Budak \\ Bartin University, Faculty of Forestry, Department of Landscape Architecture, Bartin, Turkey \\ E-mail: ferda.nur.budak@gmail.com
}

\begin{abstract}
Cities are defined in different ways in accordance with a number of qualities that distinguish them from others. The qualities come at the top of these that differ cities from others is identity of cities. It produces urban identity with natural environment and cultural structure. The city squares are the focal points of the cities with their different characteristics such as history, culture, art and architecture. These areas are the public spaces where the urban people and visitors have social, cultural, commercial and political activities. Bursa Tophane Square is a historical and touristic area located in the center of the city. One of the elements that make Tophane special is the clock tower built in 1905 and the tombs of Osman Gazi and his son Orhan Gazi, one of the founders of the Ottoman Empire. Tophane Square has various activities for visitors. In the study, a landscape design project with the aim of protection and development has been made for Tophane Square. In the design, the existing plant and the historical structure of the area were taken into consideration. Improvements were made without damaging the historical texture and the deficiencies were completed. Auto Cad 2016, SketchUp and Lumion software were used in the drawing and presentation of the project. The details of the project are presented in three dimensions as visuals. As a result of the study, it is thought that the project produced will benefit the protection of the area and improvement of the physical place quality.
\end{abstract}

Keywords: City, Square, Urban identity, Tophane Square (Bursa)

DOI: $10.7176 / \mathrm{JSTR} / 5-4-16$

\section{Koruma ve Geliştirme Bağlamında Bursa Tophane Meydanı Peyzaj Tasarım Projesi}

Özet

Kentler, onları diğerlerinden ayırt eden birtakım nitelikleri doğrultusunda farklı biçimlerde tanımlanmışlardır. Kentleri farklılaştıran bu niteliklerin başında kentin kimliği gelmektedir. Kent kimliğini, doğal çevre koşulları ve kültürel yapı ile birlikte üretir. Kent meydanları tarihi, kültürü, sanatı, mimarisi gibi değişik özellikleri ile kentlerin odak noktalarıdır. Bu alanlar yerli halk ve kenti ziyarete gelen turistlerin sosyal, kültürel, ticari ve siyasal etkinliklerini gerçekleştirdikleri, kentsel yaşamın geçtiği kamusal mekânlardır. Çalışma alanı olarak seçilen Bursa Tophane Meydanı, şehrin tam merkezinde bulunan tarihi ve turistik bir alandır. Tophane'yi özel yapan unsurlardan biri 1905 'te yapılan saat kulesi ile Osmanlı Devleti'nin kurucularından Osman Gazi ile oğlu Orhan Gazi'nin türbelerinin burada yer almasıdır. Tophane Meydanı tarihi açıdan gezip görülecek yerlerden biri olmasıyla birlikte dinlenilebilecek, çeşitli etkinlikler yapılabilecek olanaklara sahiptir. Çalışmada Tophane Meydanı için koruma ve geliştirme hedefli peyzaj tasarım projesi yapılmıştır. Tasarımda alandaki mevcut bitki varlı̆̆ ve alanın tarihi yapısı göz önünde bulundurulmuştur. Tarihi dokuya zarar vermeden iyileştirmeler yapılmış ve eksiklikler tamamlanmıştır. Projenin çizimi ve sunumunda Auto Cad 2016, SketchUp ve Lumion yazılımları kullanılmıştır. Projenin detayları üç boyutu görseller şeklinde sunulmuştur. Çalışma 
sonucunda üretilen projenin alanın korunması ve fiziksel mekân kalitesinin iyileştirilmesi şeklinde yarar sağlayacağı düşünülmektedir.

Anahtar Kelimeler: Kent, Meydan, Kent kimliği, Tophane Meydanı (Bursa)

\section{Giriş}

Kent kavramı tarihin her döneminde değişik anlamlara sahip olmuştur. Kentler; uygarlıkla sürekli eş anlamda kullanılmış ve uygarlığın kentleşme ile geldiği genel bir söylem haline gelmiştir. Günümüzde ise ülkeler kendi yasal düzenlemeleri içinde kenti belirli özelliklere göre değerlendirmektedirler. Kent kavramı sadece fiziki bir mekan ve nüfus tanımı olmanın ötesinde bir anlama sahiptir. Bu nedenle çok boyutlu ve sınırları kesin olmayan bir çalışma alanıdır ve kent hakkında farklı birçok disiplin tarafindan çalışma ve araştırmalar yapılmaktadır (Hayta, 2016)

Ortak tanımlardan hareketle kentin tarımsal olmayan üretimin yapıldığı, kontrol fonksiyonlarının toplandığı, belirli büyüklük, heterojenlik ve bütünleşme düzeylerine ulaşmış bir mekan olması ön plana çıkmaktadır. Lynch (1981), ise kentleri farklılaştıran özelliklerin başında kentin kimliğinin geldiğini vurgulamaktadır. Kentin kimliğini oluşturan, onu diğerlerinden ayıran, doğal, sosyal ve yapılı çevre arasındaki ilişki ve etkileşimlerdir. Yapılı çevreye dayalı kimlik; biçim, bulunduğu konum, kullanım türü ile bir bütün oluşturan mekansal şekillenmedir. Kentin içinde yer aldığı coğrafya, iklim, topoğrafya gibi doğal yapının, yaşam biçimi ve sosyal yapıyı etkilemesi kaçınılmazken, aynı şekilde sosyal yapının ürettiği yapılı çevrenin doğal yapıyı şekillendirmesi de kaçınılmazdır (Suher, 1998).

Kent kültürü; kent bünyesinde yaşayan insanlarca, ortak bir paydada buluşularak üretilen maddi veya manevi değerlerin oluşum sürecidir. Kente dair bir hafızanın oluşması ve üretilen kültürel çıktıların kentli insanlar aracılığı ile anlamlı hale gelmesidir. Dolayısıyla kent kültürü denildiği zaman; her kente ait farklı yorumlar ile kendine has özellikler taşıyan, fiziksel, kültürel, sosyo-ekonomik, biçimsel ve tarihsel unsurlarla şekillenen; kentliler ve onların yaşam biçimlerinden oluşan, sürekli gelişen ve sürdürülebilir kent kavramını yaşatan, geçmişte yer alan ve gelecekte de yer alacak süreçte meydana gelen anlam yüklü bütünlük anlaşılmaktadır (Ünlü, 2017).

Kent kimliği ve kültürünün önemli bir parçasını oluşturan meydanlar kültürel ve sosyal işlevleriyle ve kente olan fiziksel katkılarıyla en yaygın kentsel kamusal kullanım alanları olmuşlardır. Bu bağlamda geçmişten günümüze meydanlar kendine özgü nitelikleriyle bulundukları kentin fiziksel ve kültürel özellikleri ile kullanım amaçlarına göre şekil almışlardır (Sertkaya, 2011).

Sözlük anlamı olarak ele alındığında, geniş ve açık alan olarak tanımlanan meydanlar tarihten günümüze, insanların buluşma, toplanma, rahatlama ve dinlenme imkanı buldukları, insanların birbirini izledikleri ve kentteki olup biten olayları paylaştıkları, çok amaçlı kullanım mekanları olmuşlardır (İnceoğlu, 2007). Zamanla meydanlar içinde yer aldıkları toplumların sosyolojik yapısı ve kentin coğrafik yapısına göre farklı kimlikler kazanmışlardır.

Kent meydanları, çeşitli sosyal ve kültürel sınıfların, farklı özelliklere sahip insanların kendini ifade ettiği birbirlerini tanıyıp, deneyimlerini paylaştıkları, birbirleriyle iletişim kurmalarına olanak veren çok sesliliği barındıran mekanlardır. Toplumun her kesimini içine alan meydanlar aynı zamanda kentin kültürünü ve kimliğini yansıtan kentsel dokuda birer nirengi noktalarıdır. Toplumsal önemli olayların birçoğu meydanlarda gerçekleşmiş, meydanlar kentsel anı ve olayların tanığı olmuştur (Sertkaya, 2011). Birçok meydanların o alanı ve kenti ifade eden tarihi anıtlar ve mimari yapılar ile çevrelenmiştir. Meydanlar kuruldukları dönemin kültürünü, izlerini en iyi şekilde yansıtmaktadır. Bu alanlar insanlara sürekli ve yönlendirilmiş bir hareket düzeninden çok, durma olanağı veren ve hareketliliği zorlamayan mekanlardır (Öksüz, 2004).

Meydanların insanları çekmesinin asıl nedeni insan faktörüdür. Alanı kullanan kişi sayısı ne kadar yüksek olursa diğer kullanıcılar için alanın çekiciliği de o kadar artacaktır. Ayrıca görsel kalitenin yüksek olması ve yürüme, dinlenme, gibi etkinlikler için uygun düzenlemeler de kentliler için mekanı çekici kılacak diğer özelliklerdir. Bu bağlamda meydanların düzenlenme amacı; bireylerin açık alanda daha büyük gruplar halinde bir araya gelebilmeleri ve daha kaliteli zaman geçirebilmeleridir (Giritlioğlu, 1991).

\section{Materyal ve Yöntem}

$\mathrm{Bu}$ çalışmanın ana materyalini Bursa Tophane Meydanı oluşturmaktadır. Çalışmada tarihi meydanın kentsel dokudaki öneminin korunarak geliştirilmesi hedeflenmiştir. Kent, kimlik ve meydan üzerine yapılan literatür çalışmaları sonunda alan için yapısal ve bitkisel ögelerin yer aldığı peyzaj tasarımı geliştirilmiş̧ir. Çalışmanın yönteminde tasarımların çizilmesi ve üç boyutlu görselleş̧irilmesi amacıyla serbest el çizim teknikleri, AutoCad 2014, Photoshop CS5, SketchUp ve Lumion yazılımlarından 
yararlanılmıştır. Kentsel kamusal mekan olarak ele alınan meydanın kentsel doku, sosyal yaşam ve fiziksel çevresiyle olan ilişkisi; yapısal, bitkisel ve su kullanımları ile birlikteliğinden oluşan tasarım en çok tercih edilen kullanımlar doğrultusunda üç boyutlu görseller şeklinde sunulmuştur.

\section{Bulgular}

\subsection{Bursa Tophane Meydanı}

Bursa Tophane Meydanı, şehrin tam merkezinde bulunan tarihi ve turistik bir alandır. Tophane'yi özel yapan unsurlar tarihi saat kulesi, Osman Gazi ile oğlu Orhan Gazi'nin türbelerinin burada yer almasıdır. Seyir terası şeklinde kente hakim üst kotta yer alan meydan Bursa Kenti'nin panoramik olarak izlenebildiği bir yerdir. Tophane'de bulunan tarihi saat kulesi ilk olarak Sultan Abdülaziz döneminde yaptırılmıştır. Zamanla tahrip olan saat kulesinin yapımına 1904 yılında tekrar başlanmış ve 31 Ağustos 1905 'te tamamlanarak II. Abdülhamit'in tahta çıkışı şerefine, 31 Ağustos 1906 günü hizmete açılmıştır (URL-1, URL-2).

Tophane Meydanı tarihi açıdan gezip görülecek yerlerden biri olmasıyla birlikte her yaştan insanın serbest zamanlarını geçirebileceği, dinlenebileceği ve etkinlikler yapılabileceği olanaklara sahiptir.

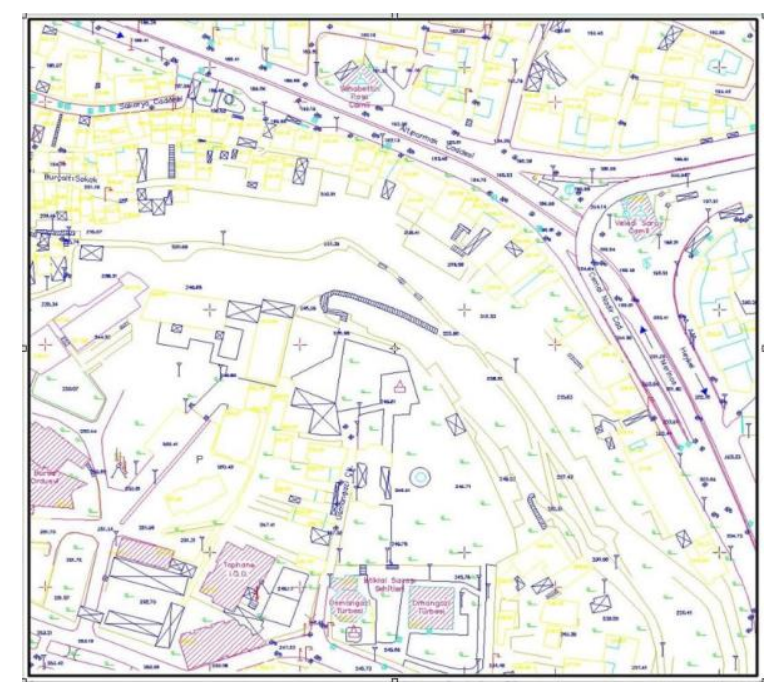

Şekil 1. Tophane Meydanı vaziyet planı

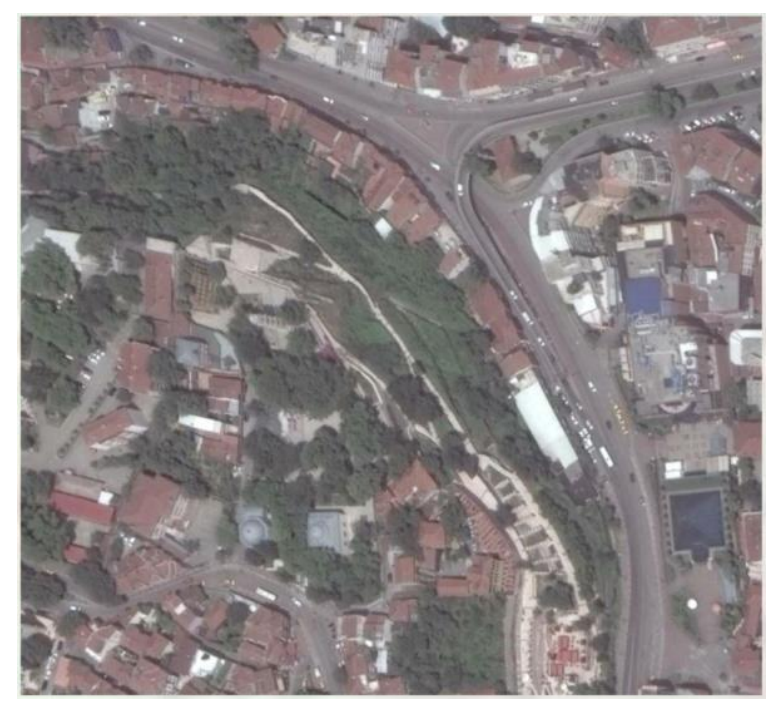

Şekil 2. Tophane Meydanı Google earth görüntüsü 


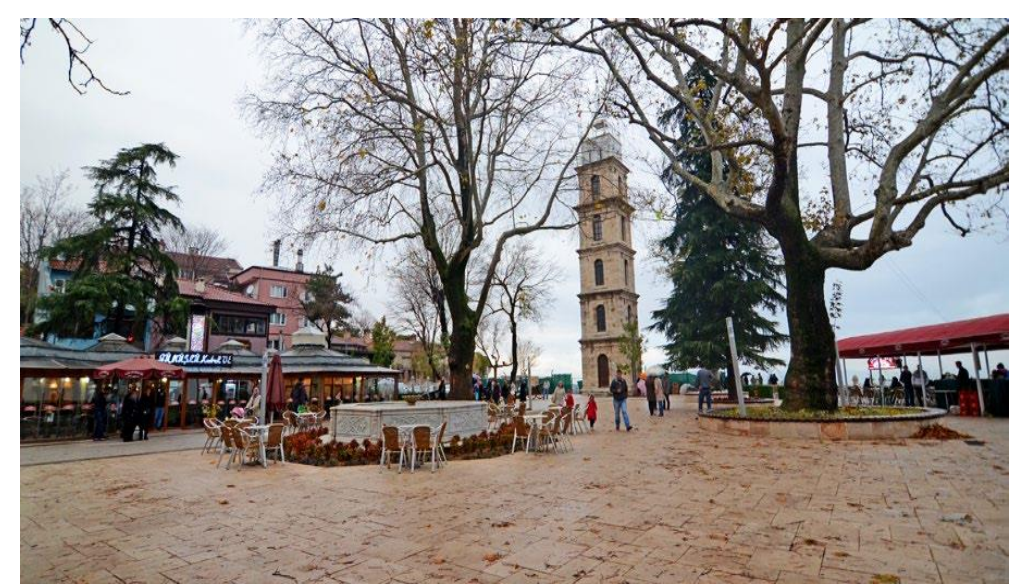

Şekil 3. Tophane Meydanı genel görünüşü

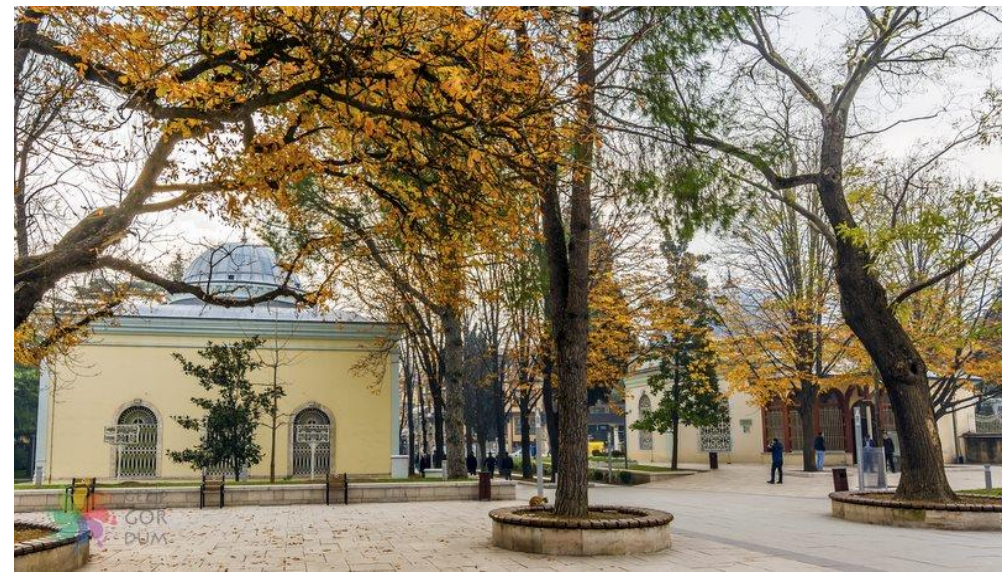

Şekil 4. Tophane Meydanı Orhangazi ve Osmangazi türbeleri

Bu alan aynı zamanda insanlar için buluşma noktası niteliğindedir. Ancak mevcut durumda çevre düzenlemesi, bitkisel ögeler, yapısal donatılar, bakım gibi sorunları bulunmaktadır. Kent halkı ve ziyaretçiler için kentin odak noktası durumundaki bu alanın yenilenmesi gerekmektedir.

\subsection{Tophane Meydanı Peyzaj Tasarım Projesi}

Proje tarihi çevre koruma ve düzenleme ve meydan tasarım ilkeleri doğrultusunda şekillenmiştir. Bu kapsamda tarihi yapıların restorasyonu, çevrelerindeki yapısal ve bitkisel düzensiz ögelerin kaldırılması ve dolayısıyla görünürlüklerinin artırılmasıyla başlamıştır.

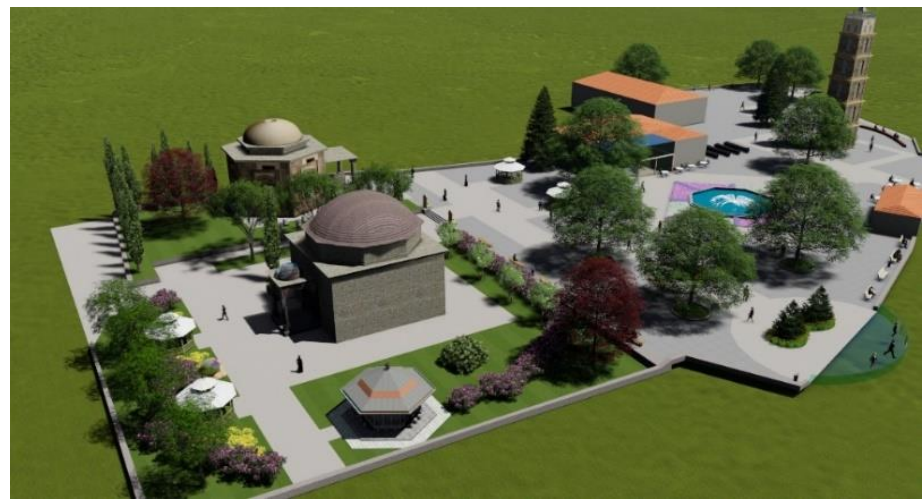

Şekil 5. Tophane Meydanı projesi genel görünüşü 


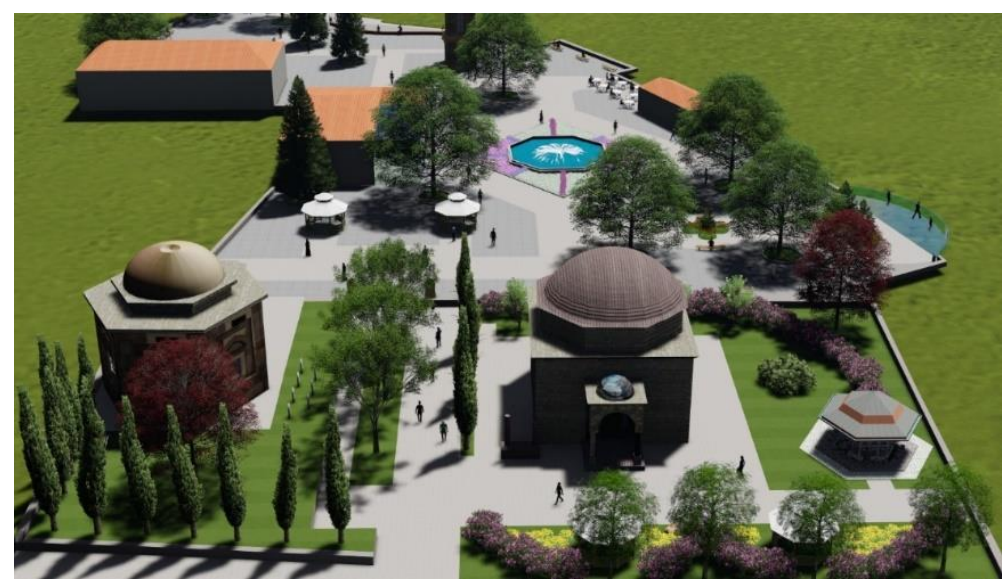

Şekil 6. Tophane Meydanı projesi türbeler yönünden genel görünüş

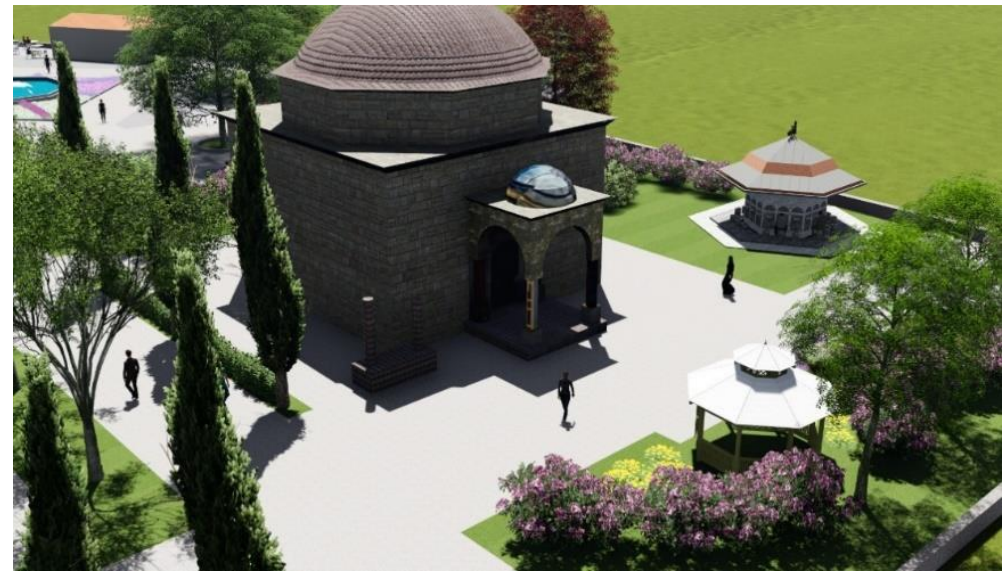

Şekil 7. Tophane Meydanı Orhangazi türbesi

Tophane Meydanı projesi yapılırken mevcut bitki varlığı ve alanın tarihi yapısı göz önünde bulundurularak tasarım yapılmıştır. Tarihi dokuya zarar vermeden iyileştirmeler yapılmış ve alanda görülen eksiklikler tamamlanmıştır. Öncelikle tarihi yapılara bakım ve onarım önerileri getirilmiştir. Türbe ziyaretine gelen misafirler kent içinden olabildiği gibi farklı şehir ve ülkelerden de olabilmektedir. İnsanların alanda daha fazla vakit geçirebilmeleri ve dinlenebilmeleri için türbe yakınında açık oturma alanları ve kameriyeler düşünülmüştür.

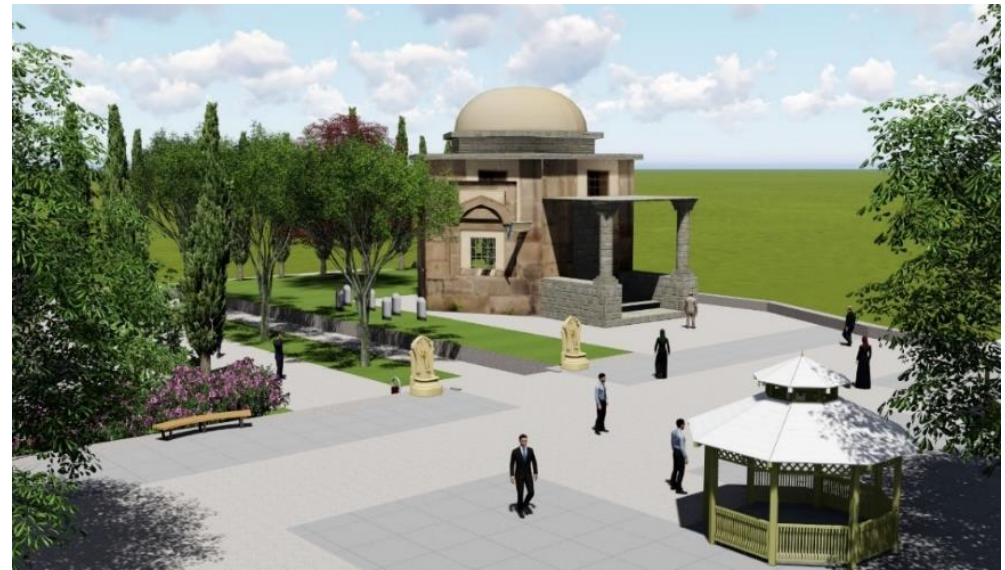

Şekil 8. Tophane Meydanı Osmangazi türbesi 


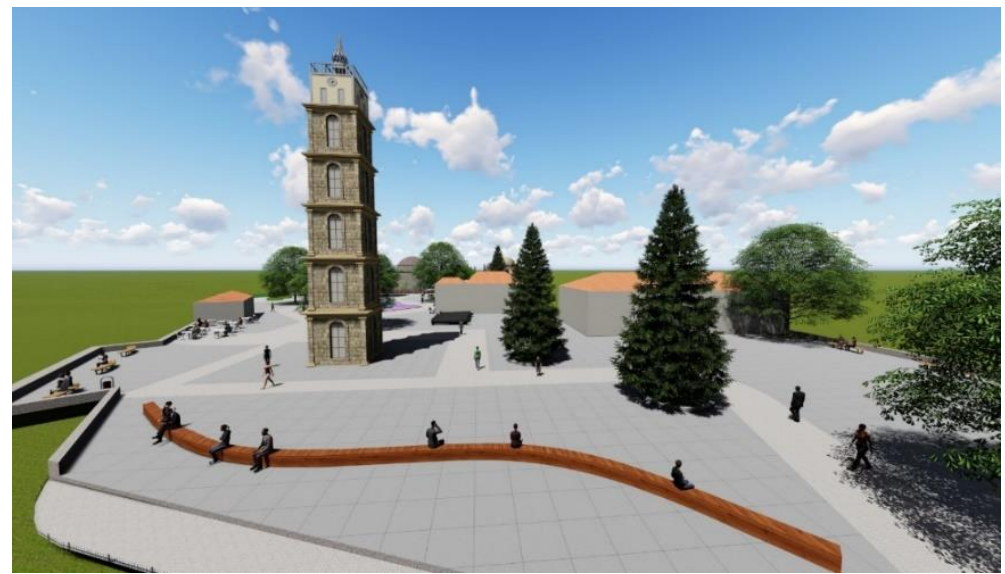

Şekil 9. Tophane Meydanı tarihi saat kulesi ve Osmanlı topları

Türbe ve yakın çevresinde şadırvan bulunmaması nedeniyle türbe yanına şadırvan düşünülmüştür. Ziyaret için gelen misafirlerin abdest alıp, ibadet edip, dinlenebileceği mekanlar tasarlanmıştır.

Alan topografya olarak yukarıda bulunduğu için özellikle yazın direk güneş ışınlarına maruz kalmaktadır. Alanı gün içinde ziyaret edenlerin rahat kullanmaları için ağaç altı banklar ile pergola ve kameriye gibi gölgeli oturma birimleri düşünülmüştür.

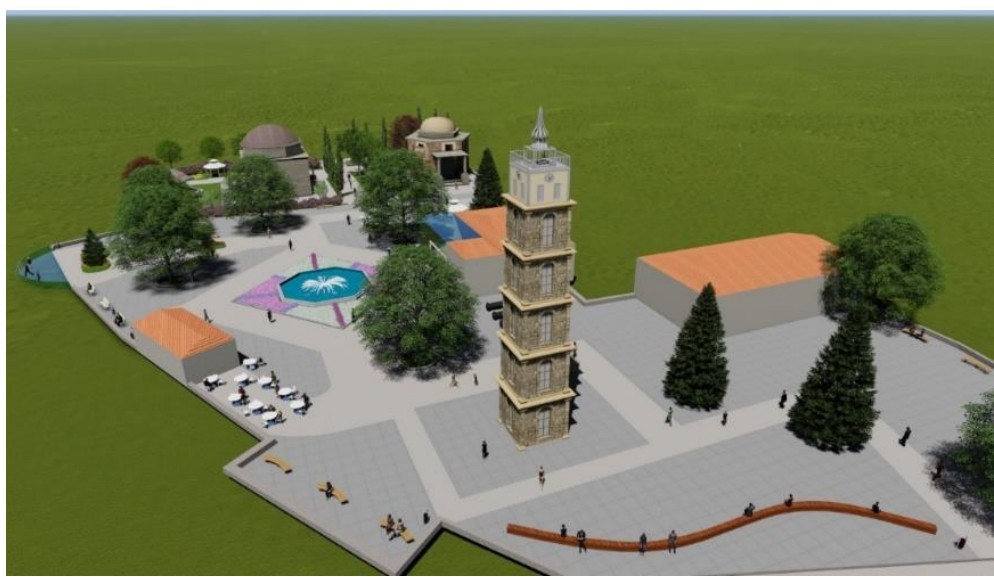

Şekil 10. Tophane Meydanı saat kulesi yönünden görünüş

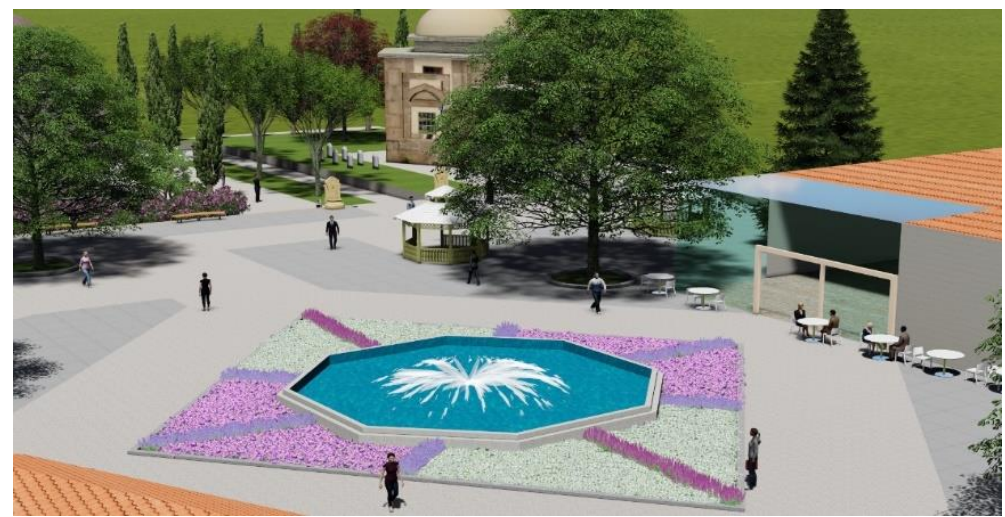

Şekil 11. Tophane Meydanı havuz ve yeme içme alanından görünüş

Tophane Meydanı'nı çekici hale getiren unsurlar arasında tarihi saat kulesi ve Osmanlı topları yer almaktadır. Bu alan aynı zamanda seyir noktası niteliğindedir. Kenti izlemek isteyenler bu alana ilgi göstermektedirler. Bu noktalarda fotoğraf çekilmek isteyen insanlar için cep şeklinde genişlemeler 
oluşturulmuştur. Mevcut durumda bu alanın yakınında oturma birimleri eksiklikleri bulunmaktadır. Bu noktalarda ahşap oturma alanları ve seyir noktaları tasarlanmış ve bakım çalışmaları önerilmiştir.

Su kullanımı peyzaj tasarımlarında önemli bir unsurdur. Suyun ses ve görüntü özelliği ile insanları rahatlatıcı etkisinden yararlanarak alanda havuz tasarımı öngörülmüştür.

Tophane Meydanı turistik gezi dışında Bursa halkı için buluşma ve seyir noktası niteliğindedir. Meydana gelen misafirler için yeme içme mekanları bulunmaktadır. Önerilen tasarımla yeme içme mekanlarının daha tanımlı olması, derme çatma veya kimliksiz yapılar yerine alanın ve kentin kimliğine uygun form ve malzeme ile yapılmaları düşünülmüştür.

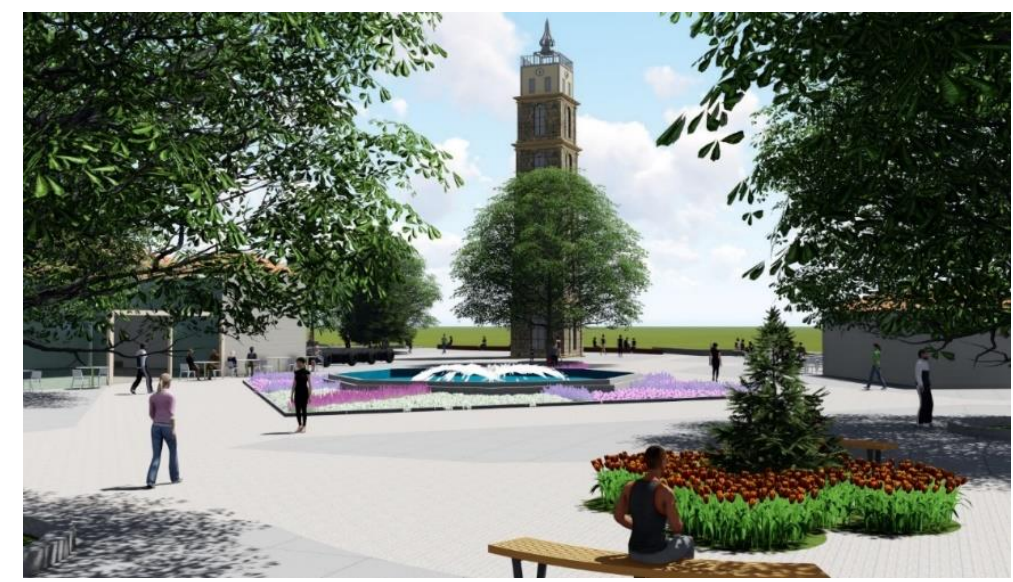

Şekil 12. Tophane Meydanı oturma alanları görünüşü

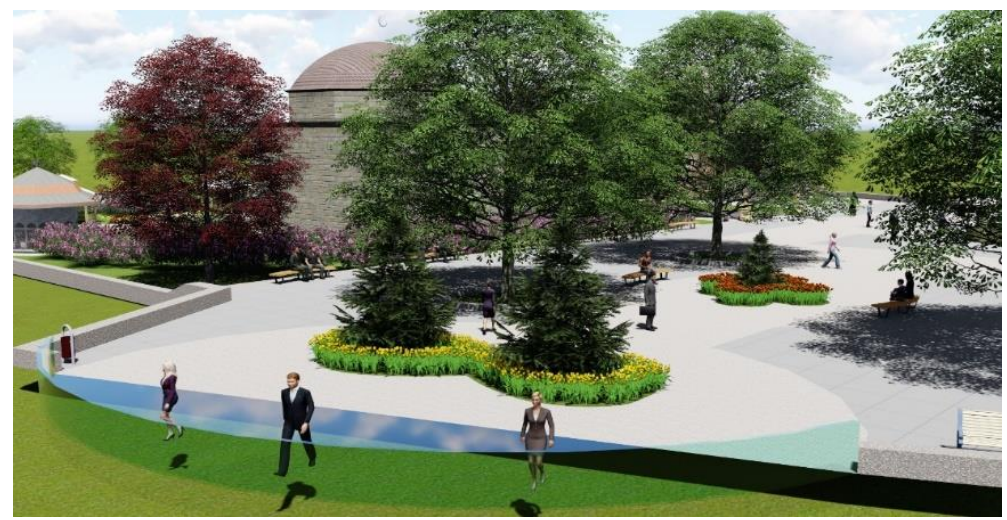

Şekil 13. Tophane Meydanı cam terastan görünüş

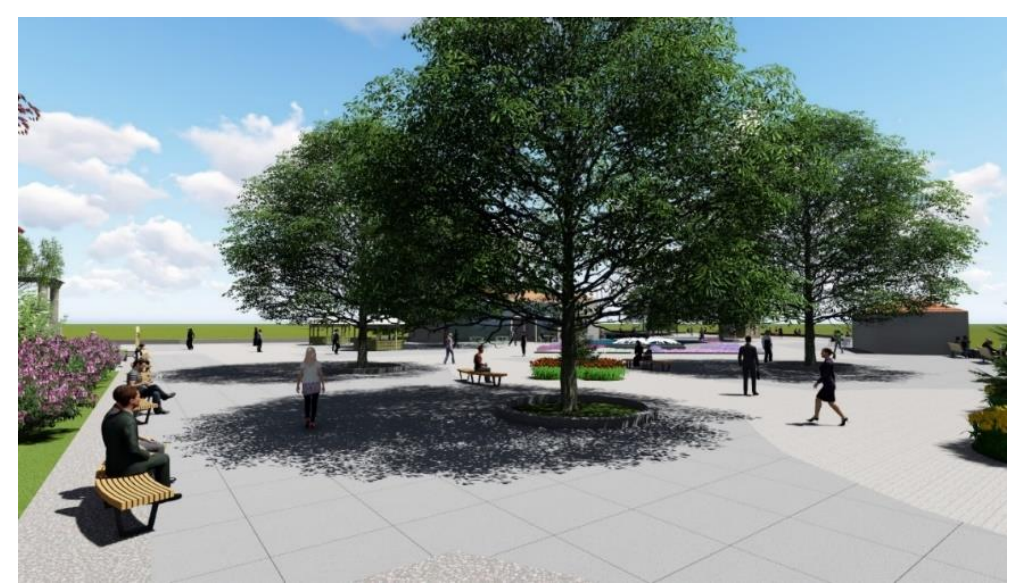

Şekil 14. Tophane Meydanı bitkisel düzenlemelerden görünüş 
Tophane Meydanı şehre en yakın seyir noktasıdır. Bu özelliği ile alan yaz ve kış gündüz ve gece kullanımlarına açıktır. Alan içinde cam teras tasarlanmıştır. Önerilen cam teras ile kış ayları ile akşam saatlerinde de ziyaretçilerin kullanabilecekleri, alanı izleyebilecekleri bir mekan oluşturulmuştur.

\section{Sonuç ve Öneriler}

Çalışma sonucunda tarihi Tophane Meydanı’nı oluşturan yapıların cephesi, yapısal ve bitkisel tasarım, meydanda bulunan kentsel donatılar, anıtsal ögeler ile diğer peyzaj öğelerinin meydanın niteliğini belirlemede önemli bir ölçüt olduğu ve dolayısıyla kullanımı etkilediği sonucuna ulaşılmıştır. Bu tespitle alan için geliştirilen tasarımlarda fonksiyonellik ve estetik bir arada düşünülmüştür.

Öneriler alanda ekonomik ve kültürel faaliyetleri, yaşama biçimi ve sosyal ilişkileri koruyacak şekilde geliştirilmiştir. Meydanda süs havuzu tasarlanmış suyun görsel ve işitsel olumlu etkisinden yararlanmak hedeflenmiştir. Alanda önerilen donatılarda malzeme ve biçim olarak kent kültürünü ve kimliğini yansitan ögeler düşünülmüştür.

Alanın etrafında ve içinde yer alan büyük bitkiler korunmuştur. Yine alan için düşünülen bitkilerin tarihi yapı ve görüntüyü kapatmayan geniş yapraklı bitkilerden oluşması gerektiğine inanılmıştır. Kullanılan bitkiler doğal bitki türlerinden olan çınar, kayın, sedir, akasya gibi türlerden seçilmiştir. Alanın Osmanlı geçmişini yansıtmak için de mevsimlik çiçeklerden lale, sümbül ve gül kullanımına devam edilmelidir. Alandaki koruma ve onarım çalışmaları yeniden yaşama katma etkinlikleri ile birlikte düşünülmüştür. Tasarımcıların en değerli katkısı, teknik bakış açısıyla ve mekanların tasarımı, organizasyonu ve kullanımı için yaratıcı fikirler üretmektir. Düşünülen peyzaj tasarım projesinin uygulanmasıyla meydanın fiziksel değeriyle birlikte yeni bir karakter kazanacağ 1 öngörülmektedir. Böylece alan yerli ve yabancı turistlerin de ilgisini çekerek kentin tanıtımına önemli katkı sağlayacaktır.

\section{Kaynakça}

Giritlioğlu, C. 1991. Şehirsel Mekan Öğeleri Ve Tasarımı, İstanbul Teknik Üniversitesi Mimarlık Fakültesi Baskı Atölyesi, İstanbul 176 S.

Hayta, Y. 2016. Kent Kültürü ve Değişen Kent Kavramı. Hakemli Makale. Bitlis Eren Üniversitesi Sosyal Bilimler Enstitüsü Dergisi. Cilt/5 Sayı/2, Bitlis

İnceoğlu, M. 2007. Kentsel Açık Mekanların Kalite Açısından Değerlendirilmesine Yönelik Bir Yaklaşım: İstanbul Meydanlarının İncelenmesi, Yıldız Teknik Üniversitesi, Fen Bilimleri Enstitüsü, Doktora Tezi, İstanbul

Sertkaya, İ. 2011. Kent Meydanları: Adana 5 Ocak Meydanı Örneği Üzerine Bir İrdeleme, Çukurova Üniversitesi Fen Bilimleri Enstitüsü Yüksek Lisans Tezi, Adana, Sayfa: 129.

Öksüz, A.M. 1999. Kentsel Alanların Planlanması ve Tasarımı, Karadeniz Teknik Üniversitesi Mühendislik Mimarlık Fakültesi Ders Notları No:54 S.340-345

Suher, H. 1998. Kent Planlama Sürecinde Kent Meydanlarının Yeri ve İşlevi. Peyzaj Mimarlığı Dergisi, Sayı: 4, Mayıs- Haziran, Özdemir Ofset, İstanbul.

Ünlü, T. 2017. Kent Kimliğinin Oluşumunda Kentsel Bellek ve Kentsel Mekan İlişkisi: Mersin Örneği. Mersin Üniversitesi, Akdeniz Kent Araştırmaları Merkezi, Mersin

URL-1 http://bursadazamandergisi.com/makaleler/tophane-parkina-sihirli-dokunus-3104.html

URL-2 https://gezipgordum.com/bursa-gezilecek-yerler/ 